gPR:M

Genual Profesi Kesehatan Masyarakat

http://jurnal.bhmm.ac.id/index.php/jpkm

${ }^{\circledR}$ Corresponding Author.

email address : yudhavika7@gmail.com

Received : 17 Juli 2021 Revised : 20 Agustus 2021 Accepted : 12 Oktober 2021

\title{
Pengaruh Pemberian Terapi Musik Campursari Langgam Jawa terhadap Tingkat Depresi pada Lansia di Pelayanan Sosial Permi Ponorogo
}

\author{
${ }^{\square}$ Yudha Fika Diliyana \& Edy Bachrun \\ Program Studi Keperawatan, Stikes Bhakti Husada Mulia Madiun, Indonesia
}

\begin{abstract}
ABSTRAK
Berdasarkan studi pendahuluan yang dilakukan di Pelayanan Sosial Permi Ponorogo. Saat dilakukan wawancara dengan menggunakan alat ukur depresi yaitu BDI (Beck Depression Inventory) terhadap 11 orang lansia, 5 diantaranya tidak mengalami depresi, 3 orang lansia mengalami depresi ringan dan 3 orang lansia mengalami depresi sedang. Gambaran perilaku lansia yang mengalami depresi ditandai dengan adanya rasa sedih 11 orang (100\%), tidak bersemangat 8 orang (73\%), suka menyendiri dan merasa tidak nyaman 3 orang (28\%). Lansia yang mengalami depresi mengatakan bahwa mereka malas dan kebanyakan lansia yang menderita depresi memilih diam di tempat tinggal mereka dari pada harus keluar bersama lansia lainnya untuk bersosialisasi 5 orang (45\%). Jenis penelitian Quasy Eksperimen dengan desain Pretest-Posttest Control Group Design. Sampel dalam penelitian ini sejumlah 34 responden. Analisa data yang digunakan adalah analisa univariat dan bivariat menggunakan Uji Mann Whitney U-Test. Dari data posttest kelompok intervensi didapatkan data sebesar 9,93 dan kelompok kontrol didapatkan data sebesar 26,06. Pada kedua kelompok tersebut, menunjukkan nilai asymp sig (2-tailed) sebesar 0,000 yang berarti HO ditolak H1 diterima, sehingga dapat disimpulkan bahwa terdapat perbedaan yang signifikan antara kelompok intervensi yang dilakukan pemberian terapi musik campursari langgam jawa dibandingkan dengan kelompok kontrol yang dilakukan pengamatan.
\end{abstract}

Kata kunci: Terapi, Musik Langgam Jawa, Depresi, Lansia.

The Effect of Giving Javanic Campursari Music Therapy on the Level of Depression in the Elderly in Social Services Permi Ponorogo

\begin{abstract}
Based on a preliminary study conducted on January 10, 2021, at the Permi Ponorogo Social Service. When interviewed using a depression measuring instrument, namely BDI (Beck Depression Inventory) to 11 elderly people, 5 of them did not experience depression, 3 elderly people experienced mild depression and 3 elderly people experienced moderate depression. The description of the behavior of the elderly who are depressed is marked by feeling sad 11 people (100\%), not excited 8 people (73\%), likes to be alone and feels uncomfortable 3 people (28\%). Elderly who are depressed say that they are lazy and most elderly who suffer from depression choose to stay where they live rather than having to go out with other elderly people to socialize 5 people (45\%). The type of research is Quasy Experiment with Pretest-Posttest Control Group Design. The sample in this study were 34 respondents. Analysis of the data used is univariate and bivariate analysis using the Mann Whitney U-Test. From the posttest data the intervention group obtained data of 9.93 and the control group obtained data of 26.06. In both groups, the asymp sig (2-tailed) value of 0.000 means that HO is rejected and H1 is accepted, so it can be concluded that there is a significant difference between the intervention group who received Javanesestyle campursari music therapy compared to the control group that was observed.
\end{abstract}

Kata kunci: Therapy, Javanese Style Music, Depression, The Elderly.

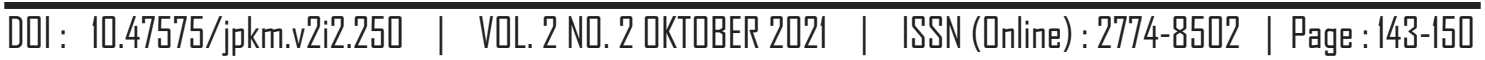




\section{PENDAHULUAN}

Berdasarkan data dari WHO (2017), menunjukkan terdapat sekitar 35 juta lansia mengalami depresi, sedangkan di Indonesia ditemukan sekitar $17,8 \%$ dari seluruh jumlah lansia. Indonesia termasuk negara yang memasuki era penduduk Indonesia berstruktur lanjut usia (aging population) karena dari tahun ke tahun jumlah penduduk Indonesia berusia 60 tahun keatas semakin meningkat. Menurut Kemenkes RI (2018), kelompok umur yang paling tinggi mengalami depresi berada di usia 70 tahun keatas. Selain itu, lansia perempuan juga lebih rentan mengalami depresi dari pada lansia laki-laki. Prevalensi data menurut RISKESDAS (2018), menujukkan prevalensi depresi total penduduk di indonesia mencapai 6,1\%, dan di Provinsi Jawa Timur kejadian depresi sebesar 4,53\%, sedangkan di kabupaten magetan 3,4\% lansia yang mengalami depresi.

Berdasarkan studi pendahuluan yang dilakukan, di Pelayanan Sosial Permi Ponorogo. Saat dilakukan wawancara dengan menggunakan alat ukur depresi yaitu BDI (Beck Depression Inventory) terhadap 11 orang lansia, 5 diantaranya tidak mengalami depresi, 3 orang lansia mengalami depresi ringan dan 3 orang lansia mengalami depresi sedang. Gambaran perilaku lansia yang mengalami depresi ditandai dengan adanya rasa sedih 11 orang $(100 \%)$, tidak bersemangat 8 orang $(73 \%)$, suka menyendiri dan merasa tidak nyaman 3 orang (28\%). Lansia yang mengalami depresi mengatakan bahwa mereka malas dan kebanyakan lansia yang menderita depresi memilih diam di tempat tinggal mereka dari pada harus keluar bersama lansia lainnya untuk bersosialisasi 5 orang (45\%).

Pada terapi musik campursari langgam jawa yang digunakan berdasarkan irama musik langgam yang memiliki tempo irama lambat, sehingga responden lansia dapat menangkap irama dari instrumen musik campursari langgam jawa tersebut. Gelombang musik yang dihantarkan ke otak dibedakan atas frekuensi alfa, beta, theta, dan delta.

Banyak manfaat yang diperoleh dengan teknik terapi musik campursari langgam jawa, diantaranya adalah menumbuhkan rasa nyaman dan membangun atau memperbaiki perasaan dan kondisi kejiwaan dari lansia. Pada penelitian ini, peneliti menggunakan terapi musik langgan jawa dikarenakan populasi yang digunakan dalam peneliti ini adalah masyarakat jawa yang sudah familiar dengan musik langgam jawa. Penggunaan terapi musik tidak memerlukan biaya dan mudah untuk di terapkan dan menyenangkan bagi lansia. Maka, berdasarkan penjelasan latar belakang diatas peneliti tertarik untuk mengetahui dan melakukan penelitian tentang pengaruh pemberian musik campursari langgam jawa terhadap tingkat depresi pada lansia di Pelayanan Sosial Permi Ponorogo.

\section{METODE PENELITIAN}

Jenis penelitian ini menggunakan jenis penelitian Quasy Eksperimen dengan desain Pretest-Posttest Control Group Design. Pada penelitian Quasy Eksperimen ini mempunyai kelompok kontrol tetapi tidak dapat berfungsi sepenuhnya untuk mengontrol variabel luar yang dapat mempengaruhi eksperimen. Sedangkan desain pretest-posttest control group design adalah dalam penelitian terdapat 2 kelompok yaitu pertama, kelompok intervensi (kelompok perlakuan) dan kelompok kedua disebut sebagai kelompok kontrol. Kedua kelompok tersebut dilakukan pretest sebelum dilakukan perlakuan (treatment). Setelah itu, perlakuan (treatment) dilakukan pada kelompok pertama sedangkan pada kelompok kedua atau kelompok kontrol tidak diberi perlakuan (treatment). Kemudian setelah kedua kelompok mendapatkan perlakuan dilakukan posttest untuk melihat adanya perbedaan atau tidak antara kelompok intervensi dan kelompok kontrol.

Populasi dalam penelitian ini adalah seluruh lansia di Pelayanan Sosial Permi Ponorogo, berjumlah 86 lansia. Jumlah sampel akhir yang dibutuhkan dalam penelitian ini adalah 16 responden dalam masing-masing kelompok. Sehingga jumlah total sampel sebanyak 32 responden.

\section{HASIL DAN PEMBAHASAN \\ Karakteristik}

Berdasarkan Gambar 1, menunjukkan bahwa pada kelompok intervensi rerata usia responden adalah 66,06 dengan standart deviasi 7,634. Usia minimal kelompok intervensi 60 tahun dan usia maksimal adalah 83 tahun. Sedangkan pada kelompok kontrol rerata usia responden 
adalah 68,67 dengan standart deviasi 6,978. Usia minimal kelompok kontrol 60 tahun dan usia maksimal adalah 80 tahun.

Berdasarkan Tabel 1, menunjukkan bahwa pada kelompok intervensi, lansia yang mengalami depresi dengan jenis kelamin lakilaki sejumlah 12 responden (75\%) dan lansia yang berjenis kelamin perempuan sejumlah 4 responden $(25 \%)$. Sedangkan pada kelompok kontrol, lansia yang mengalami depresi dengan jenis kelamin laki-laki sejumlah 8 responden $(50,0 \%)$ dan lansia yang berjenis kelamin perempuan sejumlah 8 responden $(50,0 \%)$.

\section{Data Khusus}

Dapat diketahui bahwa dari hasil uji normalitas data menggunakan Uji Shapiro-Wilk sebelum diberikan terapi musik campursari langgam jawa sebesar 0,033 dan setelah dilakukan terapi musik campursari langgam jawa sebesar 0,020 sedangkan pada kelompok kontrol didapatkan data hasil uji normalitas sebelum dilakukan pengamatan sebesar 0,038 dan setelah dilakukan pengamatan sebesar 0,020 pada kedua kelompok menunjukkan nilai signifikansi $\leq 0,05$ yang berarti distribusi data tidak normal sehingga dalam menganalisis data menggunakan uji non-parametric test yaitu dengan Uji Wilcoxon Signed Rank Test untuk mengetahui pengaruh penurunan tingkat depresi pada lansia dan Uji Mann Whitney $U$-Test untuk mengetahui perbedaan antara kelompok intervensi dan kelompok kontrol.

Berdasarkan Gambar 2, dari hasil uji homogenitas dapat diketahui bahwa jika nilai signifikansi $0,816 \geq 0,05$ maka dapat dikatakan bahwa populasi data sama atau homogen.

Didapatkan data rerata pada kelompok intervensi sebelum dilakukan terapi musik campursari langgam jawa adalah 9,51 dengan standart deviasi sebesar 1,338. Nilai tingkat depresi minimal pada kelompok intervensi 6 dan tingkat depresi maksimal adalah 10.

\begin{tabular}{|c|c|c|c|c|c|c|}
\hline Usia & Mean & Median & Modus & Min & Max & Standart Deviasi \\
\hline $\begin{array}{l}\text { Kelompok } \\
\text { Intervensi }\end{array}$ & 66,06 & 61,00 & 60 & 60 & 83 & 7,634 \\
\hline $\begin{array}{l}\text { Kelompok } \\
\text { Kontrol }\end{array}$ & 69,67 & 70,00 & 60 & 60 & 80 & 6,978 \\
\hline
\end{tabular}

Sumber: Data Diolah

Gambar 1

Distribusi Frekuensi Karakteristik Responden Berdasarkan Usia

\begin{tabular}{|c|c|c|c|c|}
\hline \multicolumn{5}{|c|}{ Test Of Normality } \\
\hline \multicolumn{5}{|c|}{ Uji Shapo-Wilk } \\
\hline Kelompok & Data & Statistic & df & Signifikansi \\
\hline Kelompok Intervensi & Pretest &, 885 & 16 & 0,033 \\
& Posttest &, 892 & 16 & 0,020 \\
\hline Kelompok Kontrol & Pretest &, 891 & 16 & 0,038 \\
& Posttest &, 875 & 16 & 0,020 \\
\hline
\end{tabular}

Sumber: Data Diolah

Gambar 2

Hasil Uji Normalitas Data Pengaruh Terapi Musik Campursari Langgam Jawa Terhadap Tingkat Depresi Pada Lansia Di Pelayanan Sosial Permi Ponorogo

Tabel 1

Distribusi Frekuensi Karakteristik Responden Berdasarkan Jenis Kelamin

\begin{tabular}{lcccc}
\hline \multirow{2}{*}{ Jenis Kelamin } & \multicolumn{2}{c}{ Kelompok Interensi } & \multicolumn{2}{c}{ Kelompok Kontrol } \\
\cline { 2 - 5 } & Frekuensi (f) & Prosentase (\%) & Frekuensi (f) & Prosentase (\%) \\
\hline Laki-laki & 12 & 75 & 8 & 50,0 \\
Perempuan & 4 & 25 & 8 & 50,0 \\
Total & 16 & $100 \%$ & 16 & $100 \%$ \\
\hline
\end{tabular}

Sumber: Data Diolah 
Sedangkan rerata sesudah dilakukan terapi musik campursari langgam jawa adalah 6,32 dengan standart deviasi sebesar 1,413. Nilai tingkat depresi minimal pada kelompok intervensi 4 dan tingkat depresi maksimal adalah 7. Pada kelompok intervensi didapatkan nilai signifikansi sebesar $0,000 \leq 0,05$ yang berarti $\mathrm{H}_{0}$ ditolak $\mathrm{H}_{1}$ diterima, sehingga dapat disimpulkan bahwa ada penurunan tingkat depresi pada lansia sebelum dan sesudah dilakukan terapi musik campursari langgam jawa di Pelayanan Sosial Permi Ponorogo.

Didapatkan data rerata pada kelompok kontrol sebelum dilakukan pengamatan adalah 8,73 dengan stadart deviasi sebesar 1,405. Nilai tingkat depresi minimal pada kelompok kontrol 6 dan tingkat depresi maksimal adalah 10. Sedangkan rerata sesudah dilakukan pengamatan adalah 9,51 dengan standart deviasi sebesar 1,296. Nilai tingkat depresi minimal pada kelompok kontrol 7 dan tingkat depresi maksimal adalah 11. Pada kelompok kontrol didapatkan nilai signifikansi sebesar $0,102 \geq 0,05$ yang berarti $\mathrm{H}_{0}$ diterima $\mathrm{H}_{1}$ ditolak, sehingga dapat disimpulkan bahwa tidak ada penurunan tingkat depresi pada lansia sebelum dan sesudah dilakukan pengamatan di Pelayanan Sosial Permi Ponorogo.

Hasil Uji Mann Whitney U-Test dari data posttest kelompok intervensi didapatkan data sebesar 9,93 dan kelompok kontrol didapatkan data sebesar 26,06. Pada kedua kelompok tersebut, menunjukkan nilai asymp sig (2-tailed) sebesar 0,000 yang berarti $\mathrm{H}_{0}$ ditolak $\mathrm{H}_{1}$ diterima, sehingga dapat disimpulkan bahwa terdapat perbedaan yang signifikan antara kelompok intervensi yang dilakukan pemberian terapi musik campursari langgam jawa dibandingkan dengan kelompok kontrol yang dilakukan pengamatan.

\begin{tabular}{|c|c|c|c|c|}
\hline \multicolumn{5}{|c|}{ Homogenity Of Varians } \\
\hline Kelompok & $\begin{array}{c}\text { Levene } \\
\text { Statistic }\end{array}$ & Dfl & Df2 & Signifikansi \\
\hline $\begin{array}{c}\text { Pretest } \\
\text { Kelompok } \\
\text { Interensi dan } \\
\text { Kelompok } \\
\text { Kontrol }\end{array}$ & 0,053 & 1 & 34 & 0,816 \\
\hline
\end{tabular}

Sumber: Data Diolah

Gambar 3

Hasil Uji Homogenitas Data Pengaruh Terapi Musik Campursari Langgam Jawa

Terhadap Tingkat Depresi pada Lansia di Pelayanan Sosial Permi Ponorogo

\begin{tabular}{|c|c|c|c|c|c|c|}
\hline $\begin{array}{c}\text { Data Tingkat } \\
\text { Depresi }\end{array}$ & N & Mean & $\begin{array}{c}\text { Standart } \\
\text { Deviasi }\end{array}$ & Min & Max & Nilai Sig \\
\hline Pretest & 16 & 9,51 & 1,338 & 6 & 10 & \multirow{2}{*}{0,000} \\
\hline Post test & 16 & 6,32 & 1,413 & 3 & 7 & \\
\hline
\end{tabular}

Sumber: Data Diolah

Gambar 4

Penurunan Tingkat Depresi pada Lansia Sebelum dan Sesudah Dilakukan Terapi Musik Campursari Langgam Jawa Pada Kelompok Intervensi di Pelayanan Sosial Permi Ponorogo

\begin{tabular}{|c|c|c|c|c|c|c|}
\hline $\begin{array}{c}\text { Data Tingkat } \\
\text { Depresi }\end{array}$ & N & Mean & $\begin{array}{c}\text { Standart } \\
\text { Deviasi }\end{array}$ & Nin & Max & Nilai Sig \\
\hline Pretest & 16 & 8,73 & 1,405 & 6 & 10 & \multirow{2}{*}{0,101} \\
\hline Post test & 16 & 9,51 & 1,296 & 7 & 11 & \\
\hline
\end{tabular}

Sumber: Data Diolah

Gambar 5

Penurunan Tingkat Depresi pada Lansia Sebelum dan Sesudah Dilakukan Pengamatan pada Kelompok Kontrol di Pelayanan Sosial Permi Ponorogo 


\begin{tabular}{|c|c|c|c|c|c|c|}
\hline Data & N & Mean & $\begin{array}{c}\text { Mean } \\
\text { Rank }\end{array}$ & Min & Max & Nilai Sig \\
\hline $\begin{array}{c}\text { Posttest } \\
\text { Kelompok } \\
\text { Intervensi }\end{array}$ & 16 & 6,32 & 9,93 & 3 & 7 & \multirow{2}{*}{0,000} \\
\cline { 1 - 5 } $\begin{array}{c}\text { Posttest } \\
\text { Kelompokk } \\
\text { Kontrol }\end{array}$ & 16 & 9,51 & 26,06 & 7 & 11 & \\
\cline { 1 - 5 }
\end{tabular}

Sumber: Data Diolah

Gambar 5

\section{Perbedaan Pengaruh Terapi Musik Campursari Langgam Jawa Terhadap Tingkat Depresi pada Lansia di Pelayanan Sosial Permi Ponorogo}

\section{PEMBAHASAN \\ Mengidentifikasi Tingkat Depresi pada Lansia Sebelum dan Sesudah Dilakukan Terapi Musik Campursari Langgam Jawa pada Kelompok Intervensi}

Berdasarkan dari hasil penelitian yang dilakukan di Pelayanan Sosial Permi Ponorogo sebelum diberikan perlakuan terapi musik campursari langgam jawa pada kelompok intervensi didapatkan hasil rerata 9,51 (kategori sedang) dan setelah diberikan perlakuan terapi musik campursari langgam jawa didapatkan hasil rerata 6,32 (kategori ringan) dengan rentang penurunan 2-4 tingkat. Dari hasil lembar kuesioner GDS sebelum dilakukan pemberian terapi musik campursari langgam jawa didapatkan 9\% lansia menyatakan tidak bahagia di sepanjang waktu dan menyatakan bahwa hidup ini tidak sangat luar biasa, 8\% lansia menyatakan lebih senang tinggal didalam kamar, tidak merasa bersemangat serta berfikir orang lain lebih baik dari diri sendiri, $7 \%$ lansia menyatakan tidak memiliki motivasi yang baik, 6\% lansia menyatakan tidak puas dengan kehidupan saat ini, merasa hidupnya hampa/kosong, merasa sering bosan, tidak tertarik dengan jalan hidupnya, dan merasa tidak punya harapan, 4\% lansia menyatakan merasa bosan dengan berbagai aktivitas, 2\% lansia menyatakan takut akan sesuatu yang buruk, 1\% lansia menyatakan merasa butuh bantuan, serta 1\% lansia menyatakan memiliki masalah dengan ingatan. Sedangkan hasil lembar kuesioner GDS sesudah dilakukan pemberian terapi musik campursari langgam jawa didapatkan 14\% lansia menyatakan berfikir bahwa orang lain lebih baik dari dirinya, 12\% lansia menyatakan tidak memiliki motivasi yang baik sepanjang waktu dan tidak merasakan bahagia, 11\% lansia menyatakan bahwa hidup ini tidak sangat luar biasa,
8\% lansia menyatakan lebih senang tinggal didalam kamar daripada keluar dan merasa tidak tertarik dengan jalan hidupnya dan $7 \%$ lansia menyatakan tidak bersemangat, serta 6\% lansia menyatakan merasa tidak memiliki harapan.

Dari data hasil penelitian yang dilakukan sebelum pemberian terapi musik campursari langgam jawa didapatkan 14\% lansia memiliki gejala depresi fisik, 57\% lansia memiliki gejala depresi psikis, dan 47\% lansia memiliki gejala depresi sosial. Sedangkan setelah dilakukan pemberian terapi musik campursari langgam jawa didapatkan 9\% lansia memiliki gejala depresi fisik, 28\% lansia memiliki gejala depresi psikis, dan 60\% lansia memiliki gejala depresi sosial. Sehingga dari data yang didapatkan, dapat disimpulkan bahwa seluruh responden pada kelompok intervensi mengalami penurunan tingkat depresi.

Penelitian tersebut sejalan dengan penelitian yang dilakukan oleh Suwarsih S,dkk (2013), tentang "Pengaruh Musik Campursari Terhadap Penurunan Skor Depresi Pada Lansia Di PSTW Unit Budi Luhur Yogyakarta" yang menyatakan bahwa terdapat pengaruh sebelum dan sesudah pemberian terapi musik campursari terhadap penurunan skor depresi pada lansia.

Berdasarkan teori Benenzon (1997), kesesuaian terapi musik sangat ditentukan dari latar belakang budaya. Sedangkan berdasarkan teori yang dikemukakan Djohan (2006) mengemukakan bahwa, efek biologis dari musik ataupun suara mampu meningkatkan ataupun menurunkan energi otot terkait dengan stimulasi dari irama, mampu mengubah cepat lambatnya tarikan nafas dan nadi, mengubah tekanan darah dan fungsi endokrin, serta mampu mempengaruhi perubahan metabolisme dan biosintesis pada berbagai proses enzim. Sehingga irama-irama musik 
yang ditangkap oleh organ pendengaran akan langsung disampaikan ke sistem syaraf pusat sehingga menimbulkan kesan tertentu di dalam diri seseorang terutama emosi. Karakteristik dari irama musik campursari langgam jawa yang lembut dan beraturan seperti detak jantung normal (60-80 kali permenit) mampu meningkatkan derajat kesehatan serta mampu mempengaruhi kerja dari susunan saraf pusat sehingga akan mengakibatkan perubahan suasana emosi.

Berdasarkan data penelitian diatas peneliti berpendapat bahwa, penurunan tingkat depresi pada lansia dikarenakan koping individu yang baik dan diberikan pemberian perlakuan terapi musik campursari langgam jawa terhadap tingkat depresi pada lansia.

\section{Mengidentifikasi Tingkat Depresi pada Lansia Sebelum dan Sesudah Dilakukan Pengamatan pada Kelompok Kontrol}

Berdasarkan dari hasil penelitian yang dilakukan di UPT Pelayanan Sosial Tresna Wherda Magetan pada kelompok kontrol sebelum dilakukan pengamatan pada lansia yang mengalami tingkat depresi didapatkan hasil rerata 8,73 (kategori ringan) dan setelah dilakukan pengamatan pada lansia yang mengalami tingkat depresi didapatkan hasil rerata 9,51 (kategori sedang). Dari hasil lembar kuesioner GDS sesudah dilakukan pengamatan didapatkan data sebagian besar responden yang mengalami peningkatan depresi sejumlah 10 responden, 2 orang responden mengalami tingkat depresi tetap, dan 3 respondenmengalami penurunan tingkat depresi. Dari hasil kuesioner lembar GDS sebelum dilakukan pengamatan didapatkan $10 \%$ lansia menyatakan tidak merasa bahagia dan berfikir bahwa orang lain lebih baik dari dirinya, 9\% lansia menyatakan bahwatidak memiliki motivasi yang baik dan merasa dirinya tidak bersemangat, $8 \%$ lansia menyatakan sering merasa bosan, $7 \%$ lansia menyatakan bahwa ini tidak sangat luar biasa dan merasa tidak tertarik dengan jalan hidupnya serta $5 \%$ lansia menyatakan bahwa tidak puas dengan kehidupan saat ini dan merasa hidupnya hampa/kosong, 4\% lansia menytakan tidak memiliki harapan, serta 3\% lansia menyatakan bosan dengan berbagai aktivitas, lebih senang tinggal didalam kamar, dan merasa memiliki banyak masalah dengan ingatannya. Sedangkan setelah dilakukan pengamatan didapatkan 9\% lansia menyatakan tidak merasa bahagia dan dan tidak bersemangat, $8 \%$ lansia menyatakan tidak puas dengan kehidupan saat ini, tidak memiliki motivasi yang baik, dan berfikir bahwa orang lain lebih baik dari dirinya, $7 \%$ lansia menyatakan tidak tertarik dengan jalan hidupnya, serta $6 \%$ lansia menyatakan merasakan hidupnya hampa/kosong, sering merasa bosan, menyatakan bahwa hidup ini tidak sangat luar biasa, 5\% lansia menyatakan tidak memiliki harapan, 4\% lansia menyatakan merasa bosan dengan berbagai aktivitas dan lebih senang tinggal didalam kamar daripada keluar, serta 3\% lansia menyatakan merasa memiliki banyak masalah.

Dari data hasil penelitian yang dilakukan sebelum dilakukan pengamatan pada lansia yang mengalami tingkat depresi didapatkan $12 \%$ lansia memiliki gejala depresi fisik, $41 \%$ lansia memiliki gejala depresi psikis, dan $62 \%$ lansia memiliki gejala depresi sosial. Sedangkan setelah dilakukan pengamatan pada lansia yang mengalami tingkat depresi didapatkan $12 \%$ lansia memiliki gejala depresi fisik, $42 \%$ lansia memiliki gejala depresi psikis, dan $43 \%$ lansia memiliki gejala depresi sosial. Sehingga dari data yang didapatkan terdapat 10 orang responden mengalami peningkatan tingkat depresi, 2 orang responden mengalami tingkat depresi tetap, dan 3 orang responden mengalami penurunan tingkat depresi.

Berdasarkan teori menurut Supartiningsih (2008) mengemukakan bahwa yang mengalam peningkatan depresi dan mengalami tingkat depresi tetap dapat dipengaruhi karena rasa kekecewaan, kurangnya dukungan dari keluarga, penolakan dari keluarga dan koping individu yang tidak baik. Dari hal-hal tersebut, dapat mempengaruhi perasaan lansia yang cenderung akan merasa sedih yang mendalam dan pembentukan hormon serotonin pada lansia akan mengalami penurunan. Dimana hormon serotonin merupakan neurotransmiter yang dapat menimbulkan rasa bahagia, sehingga dapat mempengaruhi perasaan responden. Sedangkan menurut teori Ayu D (2018) peningkatan depresi jika tidak segera ditangani dengan baik akan berefek pada isolasi diri, mencederai orang lain serta bunuh diri. 
Sedangkan lansia yang mengalami penurunan tingkat depresi disebabkan karena dukungan sosial yang tinggi dan aktif melakukan pendekatan spiritual seperti sholat, berdoa, serta aktif mengikuti kegiatan yasinan setiap hari kamis. Menurut teori Saputri (2011) mengemukakan bahwa dukungan sosial yang tinggi berupa: keberadaan orang lain yang dapat diandalkan untuk memberi bantuan, perhatian, semangat, serta mampu meningkatkan kesejahteraan hidup lansia mampu menurunkan tingkat depresi pada lansia. Sedangkan menurut teori dari Razak, dkk (2013) penanganan spiritual yang dilakukan dengan aktif mampu menyembuhkan gangguan psikologis secara sistematis berdasarkan pada keimanan dan kedekatan kepada Allah SWT.

Berdasarkan data penelitian diatas peneliti berpendapat bahwa, peningkatan depresi pada kelompok kontrol diakibatkan karena rasa kekecawaan terhadap keluarga, kurangnya dukungan, koping dari setiap responden yang kurang baik, serta tidak adanya pemberian perlakuan terapi musik campursari langgam jawa pada lansia.

\section{Menganalisis Pengaruh Pemberian Terapi Musik Campursari Langgam Jawa Terhadap Tingkat Depresi pada Lansia di Pelayanan Sosial Permi Ponorogo}

Berdasarkan hasil penelitian menunjukkan bahwa terdapat perbedaan penurunan tingkat depresi pada kelompok intervensi dan kelompok kontrol. Perbedaan tersebut teradi karena perbedaan pemberian perlakuan pada lansia yang mengalami depresi, pada kelompok intervensi diberikan perlakuan terapi musik campursari langgam jawa sedangkan pada kelompok kontrol hanya dilakukan pengamatan tingkat depresi. Dari hasil post test pada kelompok intervensi didapatkan hasil penurunan tingkat depresi pada seluruh responden sedangkan post test pada kelompok kontrol didapat hasil sebagian besar mengalami peningkatan tingkat depresi. Perbedaan dari kedua kelompok tersebut, dikarenakan pada kelompok intervensi diberikan perlakuan terapi musik campursari langgam jawa sedangkan pada kelompok kontrol tidak diberikan perlakuan terapi musik campursari langgan jawa.
Berdasarkan jurnal penelitian Widya W (2012) tentang "Efektivitas Mendengarkan Musik Langgam Jawa Keroncong Terhadap Tingkat Depresi Pada Lansia Di Shelter Gondang 2 Wukirsari Cangkringan Sleman Yogyakarta" mengatakan bahwa dari hasil mendengarkan musik langgam jawa keroncong dapat menurunkan tingkat depresi pada lansia di Shelter Gondang 2 Wukirsari Cangkringan Sleman Yogyakarta.

Berdasarkan teori menurut Purbowinoto (2011) otak memiliki 4 gelombang dengan spesifikasi masing-masingnya. Gelombang alfa untuk merelaksasi, gelombang betha berhubungan dengan mental, gelombang theta berhubungan dengan stess dan gelombang delta berhubungan dengan rasa kantuk. Pada pasien depresi terdapat malfungsi dan malformasi dari subcortic limbic dan otak bagian frontal yang mengakibatkan terjadinya perubahan secara fungsi biokimia. Seseorang yang menderita depresi terdapat asimetris pada alfa dan hipoaktivasi dari otak kiri yang menyebabkan terjadinya psikopatologi pada emosional dan mencetuskan terjadinya depresi. Pada musik campursari langgam jawa memiliki komponen yaitu nada dan irama yang dapat memberi pengaruh psikologis dan fisiologis pada tubuh. Saat rangsangan suara terdengar di gendang telinga yang kemudian akan diteruskan ke susunan saraf pusat tepatnya pada sistem limbic. Sistem limbic memiliki fungsi sebagai neurofisiologi yang berhubungan dengan emosi (kesedihan, nyeri, kegembiraan serta kenangan yang mendalam bagi seseorang), perasaan dan sensasi. Terapi musik campursari langgam jawa memiliki efek terhadap gelombang alfa. Dengan sesampainya stimulus dari musik akan membentuk gelombang alfa yang sempurna dan merangsang pelepasan neurotransmiter yaitu hormon serotonin. Hormon serotonin dapat menimbulkan rasa bahagia, karena merupakan neurotransmiter yang mempengarui perasaan. Selanjutnya serotonin akan dirubah menjadi hormon melatonin yang memberikan efek relaksasi dan perubahan mood sehingga dapat menurunkan depresi yang dirasakan. 
Berdasarkan kesimpulan diatas peneliti berpendapat bahwa, terdapat perbedaan pengaruh terapi musik campursari langgam jawa terhadap tingkat depresi pada lansia di Pelayanan Sosial Permi Ponorogo. Selain itu, penggunaan terapi musik campursari langgam jawa merupakan salah satu teknik relaksasi yang menyenangkan bagi lansia, tidak mengeluarkan biaya dan mudah untuk didapatkan.

\section{SIMPULAN}

Setelah dilakukan identifikasi terhadap penurunan tingkat depresi dengan dilakukan pemberian terapi musik campursari langgam jawa pada kelompok intervensi menggunakan Uji Wilcoxon Signed Rank Test didapatkan rerata pretest 9,51 yang termasuk dalam kategori depresi sedang dan rerata post test 6,32 yang termasuk dalam kategori depresi ringan. Setelah dilakukan identifikasi terhadap penurunan tingkat depresi dengan dilakukan observasi pada kelompok kontrol menggunakan Uji Wilcoxon Signed Rank Test didapatkan rerata pretest 8,71 yang termasuk dalam kategori depresi ringan dan rerata post test 9,51 yang termasuk dalam kategori depresi sedang. Terapi musik campursari langgam jawa berpengaruh dengan hasil menurunkan tingkat depresi pada lansia di Pelayanan Sosial Permi Ponorogo. Diharapkan untuk meneruskan dan mengembangkan penelitian secara mendalam dengan menambah variabel penelitian yang berbeda, menambah frekuensi waktu penelitian dan melakukan pengamatan setiap hari.

\section{DAFTAR PUSTAKA}

Ayu, Dyah R K. 2018. Efektifitas Pemberian Terapi Tertawa Dan Terapi Spiritual Terhadap Perubahan Tingkat Depresi Pada Lansia Di PSTW Magetan. Laporan Tugas Akhir, Program Studi Keperawatan Stikes Bhakti Husada Mulia Madiun.

Djohan, 2006. Terapi Musik (Teori Dan Aplikasi). Yogyakarta: Galang Press.

Hawari, D. 2011. Manajemen Stress, Cemas, dan Depresi. Jakarta: FKUI.
Mutiah, D L. 2017. Pengaruh Terapi Musik Terhadap Tingkat Kecemasan Sebelum Bertanding Pada Atlet Futsal Putri Tim Muara Enim Unyted. Skripsi. Program Studi Keolahragaan UNIVERSITAS NEGERI YOGYAKARTA.

Purbowinoto, S. E., \& Kartinah. 2011. Pengaruh Terapi Musik terhadap Perubahan Tingkat Depresi pada Lansia di PSTW (Panti Sosial Tresna Wherdha) Unit Budi Luhur, Kasongan, Bantul Yogyakarta.

Razak, Ahmad. Dkk. 2013. Terapi Spiritual Islami Suatu Model Penanggulangan. Gangguan Depresi.

Riset Kesehatan Dasar Riskesdas. 2018. Badan Penelitian dan Pengembangan Kesehatan Kementrian RI Tahun 2018. https://www.depkes.go.id/ resources/download/infoterkini/materi rakorpop_2018/Hasil\%Riskesdas\% 20 2018.pdf

Saputri, M \& Indrawati, E. 2011. Hubungan Antara Dukungan Sosial dengan Depresi pada Lanjut Usia yang Tinggal di Panti Werdha Wening Wardoyo Jawa Tengah. Jurnal Psikologi Undip, 9(1).

Supartiningsih. 2008. Faktor-Faktor yang Berhubungan Dengan Kejadian Depresi Pada Lanjut Usia Yang Tinggal di PSTW Budi Luhur Yogyakarta. Program Study Ilmu Keperawatan STIKES Aisiyah Yogyakarta.

Suwarsih, S., Kirmantoro \& Wahyu D. S. 2013. Pengaruh Musik Campursari Terhadap Penurunan Skor Depresi Pada Lansia Di PSTW Unit Budi Luhur Yogyakarta.

Widya, W. Swara. 2012. Efektifitas Mendengarkan Musik Langgam Jawa Keroncong Terhadap Tingkat depresi Pada Lansia Di Shelter Gondang 2 Wukirsari Cangkringan Sleman Yogyakarta. Karya Tulis Ilmiah. Program Studi Ilmu Keperawatan Universitas Muhammadiyah Yogyakarta. 